\title{
Integrated Index in Consideration of Appropriate Plastic Recycling System in Waste Bank Operation
}

\author{
Noorhan Firdaus Pambudi ${ }^{1,2,{ }^{*}}$, Kiyoshi Dowaki ${ }^{1}$, and Akbar Adhiutama ${ }^{2}$ \\ ${ }^{1}$ Tokyo University of Science, 2641 Yamazaki, Noda-shi, Chiba-ken 278-8510, Japan \\ ${ }^{2}$ Institut Teknologi Bandung, Jalan Ganesha No. 10 Bandung 40132, Indonesia
}

\begin{abstract}
Several appropriate technology had been developed to maintain plastic waste in society according to minimize environmental impact. Landfill is no longer appropriate to maintain plastic waste based on the environmental impact that might be occurred for instance. However in developing countries such as Indonesia, although plastic recycling technology have been promoted by maintain waste bank policy for support community willingness to exchange their recyclable waste with certain monetary values, there is no guarantee that community will fully accept plastic recycling technology. This research aims to assess the performance of plastic recycling in environmental and social aspects as its integrated index. From that assessment, appropriate strategies in plastic recycling will be delivered in this research. Environmental aspects will be assessed by using life cycle assessment (LCA) through MiLCA software and selected by using data envelopment analysis (DEA). Social aspects will be analyzed by using qualitative and quantitative methodology such as observation, interview, secondary data, and questionnaires. Simulation and modelling will also developed by using agent-based modelling (ABM) to describe social dynamic of community in supporting waste bank policy. The appropriate system of plastic recycling will be promoted as expected results for this research.
\end{abstract}

\section{Research Background}

Increasing the number of population in Indonesia, the serious problem of amount of waste generated in the community has been caused. The government of Indonesia has proposed several policies to solve this problem. For instance, one strategy is the promotion of waste bank. In the waste bank, the waste transaction is executed then the provider can obtain the monetary value as mentioned in "Peraturan Menteri Lingkungan Hidup No. 13" [1]. This system needs participation from community to sustain in the household waste management system. Also, the success or failure of the waste bank operation would be affected by the different preferences of residential people.

Waste bank is one policy for maintaining appropriate technology which represented by plastic recycling technology and community empowerment which represented by

\footnotetext{
* Corresponding author: noorhan.firdaus@sbm-itb.ac.id
} 
community willingness to exchange their waste to waste bank. There are two aspects in integrated index in this research, social aspects and environmental aspects. Social aspects lie on community acceptance and participation in supporting plastic recycling. Environmental aspects lie on technological appropriateness in perform better impact to environment for a plastic waste treatment. This study aims to develop and measure both of indexes in one integrated index to find appropriateness of the policy in waste bank in terms to develop plastic waste recycling technologies.

For plastic waste treatment, this research develops several scenarios or strategies to maintain plastic waste in Bandung including current treatment of plastic waste which uses landfill. Proposed scenario in this research is promoting plastic waste recycling in community with several modifications for each strategy. There are 5 scenarios proposed in this research,

- Scenario 1 : all plastic waste will be sent to landfill

- Scenario 2 : 50\% of plastic waste will be sent to landfill, the rest will be incinerated with energy recovery

- Scenario 3 : all plastic waste will be incinerated with energy recovery

- Scenario 4 : all plastic waste will be recycled, scrap of remanufacturing process will be sent to landfill

- Scenario 5 : all plastic waste will be recycled, scrap of remanufacturing process will be incinerated with energy recovery

Therefore, this study will answer following research questions:

RQ1 How is currently plastic waste management performed in Bandung?

RQ2 What policy should be necessary taken by government to support plastic recycling in plastic waste management system?

RQ3 What kind of appropriate system or technology should be implemented to support plastic recycling system based on its opportunities and challenges?

\section{Research Boundaries}

The study will be focused on plastic waste management system in Bandung (Figure 1). The study also reach each value chain of plastic waste which is started from plastic waste generated by community in household, plastic waste collected by local government within or without waste bank, and up until plastic waste remanufacturing process. It also focused on household waste management system specifically in plastic waste. Since waste in Bandung categorized into organic and non-organic waste, so this study will covered nonorganic waste and its stakeholder who connected with it. Stakeholders who will be considered lie from local government, community, and industry.

Research Boundaries

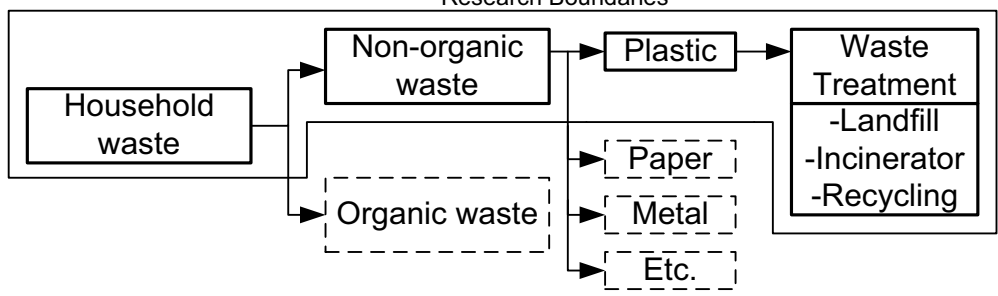

Fig. 1. Research Boundaries. 


\section{Research Methodology}

All scenarios will be assessed by using LCA through MILCA software. The most effective scenario will be selected by using DEA. This measurement is applied for maintaining environmental performance of each proposed strategy. Decision making will also consider social performance of each strategy by analyzing community empowerment using qualitative methodology through observation or interview and quantitative methodology through questionnaire. Observation will be conducted in waste collection process from waste bank administrators to analyze community empowerment in supporting waste bank operation. Interview will be targeted to community and several cleaning service officer to develop needs in community to support plastic recycling in Bandung.

\section{State of the Art and Research Gap}

\subsection{Life cycle assessment of plastic waste management system}

By using LCA modelling, previous study conducted by Manfredi and Christensen [2] compared the environmental performance of six landfill technologies which conventional landfill had greater impact if there is no innovation to reduce environmental impact. The study from Yay [3] conclude that landfill and incineration have been confirmed as the worst waste final disposal alternatives, composting and material recovery showed better performance. Thus, landfill and incinerator without any combination of another waste treatment technology could give a bad impact to environment. Other previous study conducted by Fikri et al. [4] took an object in Indonesia especially in household hazardous waste management in Semarang had been conducted. The result showed that recycling HHW is the best scenario based on the LCA approach. Another study conducted by Arena et al. [5] defined through the analytical comparison between the six scenarios showed that the recycling option always environmentally preferable. Another study from Perugini et al. [6] confirmed that recycling scenarios are always preferable to those of non-recycling. Thus, recycling is one appropriate technology which could be considered to avoid greater impact to environment.

Previous study conducted by Matsuda et al. [7] was also focused on food waste which was resulted that prevention of food losses enhanced by separate collection lead to a significant reduction in GHG emissions. Another study conducted by Scortar and Suciu [8] covered that recycling rate is increasing in several countries especially in well-developed country such as OECD countries. Recycling idea is becoming one strategy that implemented in several countries to avoid greater impact in environment.

\subsection{Social simulation in environmental aspect of community}

Throughout the previous study conducted by Shi et al. [9] concluded that even when the participation rates increased, bottleneck facilities were found to be one of the primary obstacles when increasing recycling rates in several countries. Therefore, for those cases, strategic planning of capital projects, including both the bottleneck facilities' expansion and new facilities' construction is recommended in those studies. Without any improvement in infrastructure which was supported recycling system, the strategy would not sustain in the long terms. Another latest paper conducted by Suvageau and Frayret [10] proposed an agent-based simulation model to study and analyze the performance of various procurement and production policies in the recycled paper industry. Social simulation become one methodology to see the behaviour occurred in community related to support environmental 
friendly technologies or strategies. Previous study conducted by Liu and Ye [11] was also explored the evolvement of firm's environmental behaviour and influencing factors. There are several type of behaviour should be defined to conduct social simulation in related to environmental behaviour in our community.

\subsection{Waste bank and plastic waste recycling system}

Previous study conducted by Thanh et al. [12] about potential plastic recycling of household solid waste in Vietnam which household income and household size become existing correlation to plastic waste generation in detailed composition. Thus study concluded that household habits and behaviours of plastic waste discharge and the aspect of environmental impacts and resource consumption for plastic waste disposal alternatives were also evaluated. From other study conducted by Scortar and Suciu [8] said that the current waste management policies highlighted the importance of an integrated approach to waste management, which includes construction of facilities for waste disposal, together with measures to prevent waste generation and recovery measures, in accordance with the waste management hierarchy: waste prevention, quantity minimization, waste recovery and safe ultimate storage where there is no possibility of recovery. Another study conducted by Barterlings and Sterner [13] found that economic incentives, although important, are not the only driving force behind the observed reduction in municipal waste. Given the proper infrastructure that facilitates recycling, people are willing to invest more time than can be motivated purely by savings on their waste management bill. Another important result was that perceptions about the difficulties related to recycling and composting are important determinants of the effort people are prepared to make. Economic value of plastic waste and community occurred to evaluate plastic recycling technologies or systems. Waste bank strategies in this study conclude that aspect to evaluate the current system of plastic recycling.

\section{Data Collection}

\subsection{Plastic waste volume}

Secondary data which support to describe current situation of plastic waste recycling system will be gathered. This data will support the process of Life Cycle Assessment and Data Envelopment Analysis to give current performance in environmental aspect of plastic waste recycling system. The data also collected by using questionnaire to describe daily consumption of plastic waste in community. Table 1 show the specific percentage of waste type from 1981 until 2001 which have been collected by Deputi Bidang Analisa Sistem BPPT [14]. The data show that organic waste was dominated the number of waste generated by community and plastic waste percentage increasing year by year. 
Table 1. Percentage of Waste 1981-2001.

\begin{tabular}{|c|c|c|c|c|c|c|c|c|c|c|c|}
\hline \multirow{2}{*}{$\begin{array}{c}\text { Compone } \\
\text { nt }\end{array}$} & \multirow{2}{*}{$\begin{array}{c}\text { Uni } \\
\mathrm{t}\end{array}$} & \multicolumn{10}{|c|}{ Year } \\
\hline & & 1981 & 1983 & 1985 & 1989 & 1997 & 1998 & 1999 & 2000 & 2001 & 2002 \\
\hline Organic & $\%$ & 79.49 & 77.90 & 73.97 & 79.37 & 74.60 & 75.38 & 75.18 & 74.99 & 74.60 & 74.22 \\
\hline Paper & $\%$ & 7.97 & 6.70 & 8.28 & 8.57 & 10.18 & 10.50 & 10.71 & 10.93 & 11.15 & 11.37 \\
\hline Wood & $\%$ & 3.65 & 2.97 & 3.94 & 0.75 & 0.98 & 0.39 & 0.20 & 0.02 & 0.02 & 0.02 \\
\hline Textile & $\%$ & 2.40 & 1.98 & 3.05 & 0.79 & 1.57 & 1.20 & 1.13 & 1.06 & 1.00 & 0.93 \\
\hline Rubber & $\%$ & 0.47 & 0.94 & 0.52 & 0.33 & 0.55 & 0.41 & 0.39 & 0.37 & 0.35 & 0.33 \\
\hline Plastics & $\%$ & 3.67 & 5.13 & 5.64 & 6.51 & 7.88 & 8.11 & 8.30 & 8.50 & 8.69 & 8.88 \\
\hline Metal & $\%$ & 1.37 & 1.93 & 2.04 & 1.45 & 2.04 & 1.89 & 1.89 & 1.90 & 1.90 & 1.90 \\
\hline Glass & $\%$ & 0.50 & 0.65 & 1.55 & 1.57 & 1.75 & 1.93 & 1.99 & 2.05 & 2.10 & 2.16 \\
\hline Battery & $\%$ & 0.48 & 1.80 & 0.97 & 0.48 & 0.29 & 0.01 & 0.01 & 0.01 & 0.01 & 0.01 \\
\hline Others & $\%$ & & & & 0.18 & 0.18 & 0.18 & 0.18 & 0.18 & 0.18 & 0.18 \\
\hline Total & $\%$ & 100 & 100 & 100 & 100 & 100 & 100 & 100 & 100 & 100 & 100 \\
\hline
\end{tabular}

Table 2 shows the specific proportion of plastic waste type in Surabaya and Jakarta from report conducted by Deputi Bidang Analisa Sistem BPPT [15]. HDPE, LDPE, and PP are the most contributed plastic waste which generated in both cities. Lesson learned from Surabaya showed that there is a decreasing number of waste tonnage sent to landfill according to an increasing number of waste bank developed. The data from previous research conducted by Wijayanti and Suryani [16] showed that the reduce of waste tonnage has been achieved, up to 7,14 tons per week. In 2005, the number of population was 2.740.490, and waste sent to landfill is $1.819 \mathrm{~m}^{3}$. This amount had been decreased until 2011. In accordance, the number of waste bank in Surabaya increased from 2010 to 2012 by more than $50 \%$ and $30 \%$ from 2012 to 2013 . All data were concluded that waste bank improvement will impact to decreasing number of waste which will be sent to landfill. Improvement of developing new waste bank and improvement of performance of waste bank is necessary to be conducted in terms to avoid bad impact of landfill as an option of waste management system.

Table 2. Proportion of Plastic Waste in Surabaya and Jakarta.

\begin{tabular}{|l|r|r|}
\hline Component & Surabaya & Jakarta \\
\hline LDPE & 1.01 & 0.78 \\
\hline PP & 2.64 & 2.03 \\
\hline HDPE & 3.97 & 3.05 \\
\hline PVC Bottle & 0 & 0 \\
\hline PVC Film & 0.15 & 0.12 \\
\hline PET & 0.09 & 0.07 \\
\hline Styrofoam & 0.08 & 0.07 \\
\hline Others & 0.54 & 0.41 \\
\hline
\end{tabular}

\subsection{Observation and interview}

Observation conducted during waste bank operated in collecting plastic waste in community. This research followed and analyzed several phenomena occurred during waste collection phase of waste bank. This study defines several characteristic of community who is involved in collecting plastic waste and exchange plastic waste into certain monetary 
value. Interview conducted to several respondents who involved in waste bank operation, waste management system, and plastic recycling industries. This research aims to analyzed problems and limitations that occurred in promoting plastic waste recycling system. Thus, appropriate system will be promoted while several evaluation and improvement proposed into current situation of plastic waste recycling system.

\section{Proposed Integrated Index in Plastic Waste Management}

There two parts of indexes will be discussed in this research, environmental and societal aspects of plastic recycling in waste management system. Both of them will be integrated in terms to find the opportunities and challenges of plastic recycling implementation in current waste management system. Environmental aspects will be covered by using life cycle assessment which will be comparing five scenarios which already explained in chapter 1 . Meanwhile, societal aspects will be observed by using simulation and modelling approach specifically using agent-based modelling since the context is lie on community involvement and acceptance of plastic recycling technology.

First scenario, plastic waste will be delivered to landfill as their final waste treatment which is occurred in business as usual. Second scenario, half of plastic waste will be sent to landfill and the rest will be incinerated with energy will be recovered. Third scenario, all plastic waste will be incinerated with energy will be recovered. Fourth scenario, all plastic will be recycled and production waste will be sent to landfill. Last scenario, all plastic will be recycled and production waste will be incinerated with energy will be recovered. The model of each scenario can be seen in Figure 2.

Societal aspects that will be included in this research is cost of maintaining plastic recycling in community and willingness of community to adopt the system which support plastic recycling. Cost of maintaining recycling in community contains of cost of waste collection, cost of waste transportation, and cost of waste storage. Cost of waste collection is occurred in collecting phase of waste started from community to temporary storage of waste or waste bank. The model of the simulation can be seen in Figure 3. Several data from qualitative research will support the result in environmental and societal aspect. The result will be considered to maintain more sustainable and appropriate system in community.

\begin{tabular}{|c|c|c|c|c|c|}
\hline & Scenario 1 & Scenario 2 & Scenario 3 & Scenario 4 & Scenario 5 \\
\hline Landfill & 0 & $0 \quad 9$ & ash & & $\oint^{\text {ash }}$ \\
\hline Incinerator & & 0 & 0 & & \\
\hline Recycling & & & & & \\
\hline $\begin{array}{l}\text { Product waste } \\
\text { landfill }\end{array}$ & & & & 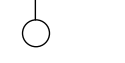 & \\
\hline $\begin{array}{l}\text { Product waste } \\
\text { incinerator }\end{array}$ & & & & & \\
\hline
\end{tabular}

Fig. 2. Scenario of Life Cycle Assessment.

The model of simulation which showed in Figure 3 is explain the changing behaviour in community based on the changing of cost (c) according to monetary value of waste (p). Community will compare between this two variables to maintain their decision of willingness to adopt the system which support plastic recycling. In respond to that difference, community will be classified into three types which are adapting community, 
careless community and arguing community. Initial state of community will be called as common-community who not decides their willingness yet according to condition of differences between cost and monetary value still unrecognized. Adapting communities are peoples who willing to adopt the system in every single condition of differences between cost and monetary value. Arguing community are people who not willing to adopt the system according the monetary value is less than cost that must be spent by them, this kind of community can change their decision if the differences of monetary value and cost changing (monetary value higher than cost). Careless community are people who will not adopt the system even the monetary value is higher than cost that will be spent by them.

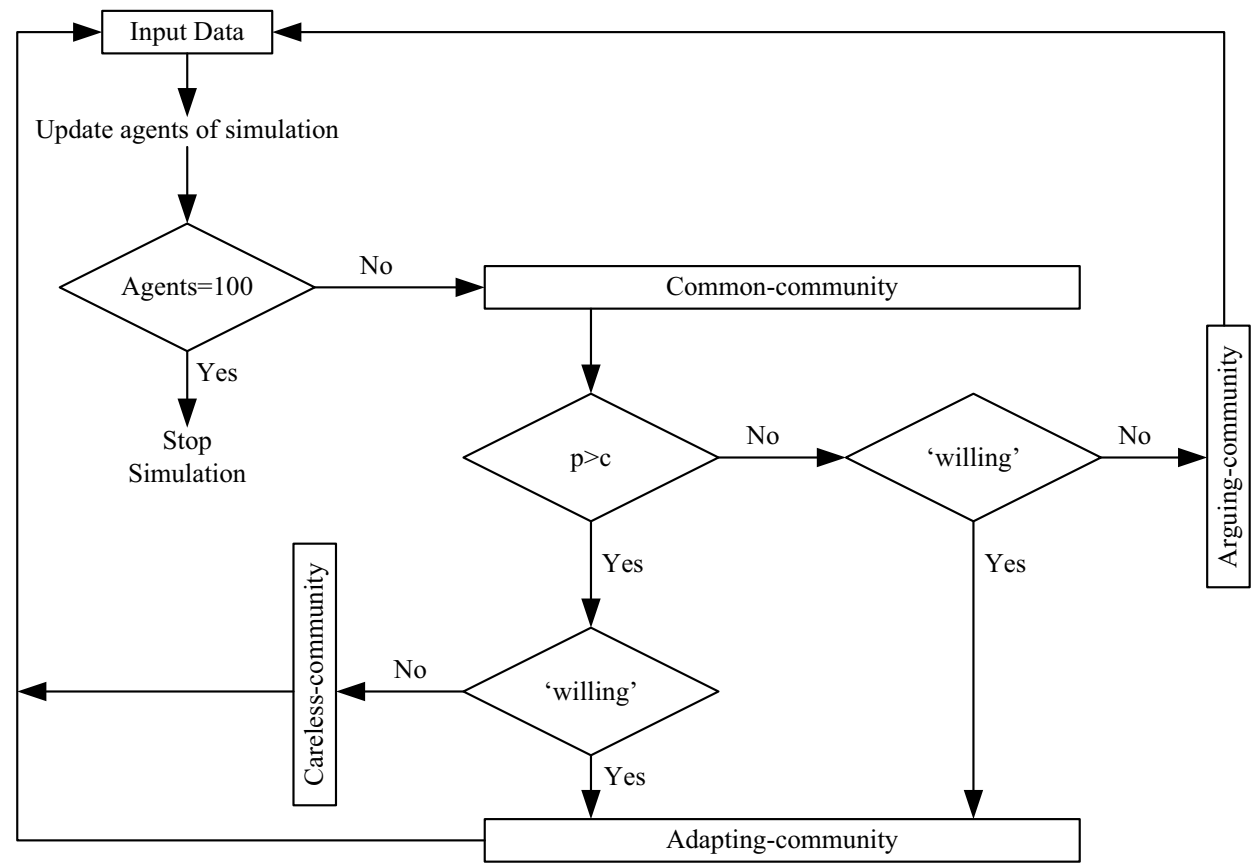

Fig. 3. Model of Societal Aspects using Agent-based Modelling.

\section{Expected Result and Discussion}

\subsection{LCA and DEA Result}

Through life cycle assessment, this research covered emission from each scenario as described in Table 3. From each emission which is occurred, scenario 1 and 2 has the worst impact in all emissions. This calculation assessed from green house gas emission in life cycle assessment using MiLCA. Scenario 3, 4, and 5 had has better result in green house gas emission. This study conclude that plastic waste can be treated using landfill which is still used in business as usual in Bandung and several city in Indonesia. Recycling and incinerator should be considered as alternative in treat plastic waste in Indonesia. Even scenario 4 , which use landfill to treat production waste from recycling activity, still have a better performance in environmental impact especially in green house gas emission than landfill strategy (represented by scenario 1 and 2). 
Table 3. Emission of each Scenario.

\begin{tabular}{|c|c|c|c|c|c|c|}
\hline $\begin{array}{c}\text { Elementary } \\
\text { flow }\end{array}$ & Scenario 1 & Scenario 2 & Scenario 3 & Scenario 4 & Scenario 5 & Unit \\
\hline $\begin{array}{c}\text { carbon } \\
\text { dioxide } \\
\text { (biogenic) }\end{array}$ & 0.039103965 & 0.029360454 & 0.019616944 & 0.020835714 & 0.020839432 & $\mathrm{Kg}$ \\
\hline $\begin{array}{c}\text { carbon } \\
\text { dioxide } \\
\text { (fossil) }\end{array}$ & 0.038399083 & 0.000153408 & 0.000153187 & 0.000153867 & 0.000153922 & $\mathrm{Kg}$ \\
\hline methane & 0.044838288 & 0.025911523 & 0.007030841 & 0.007431663 & 0.007413497 & $\mathrm{Kg}$ \\
\hline $\begin{array}{c}\text { methane } \\
\text { (fossil) }\end{array}$ & $5.92 \mathrm{E}-07$ & $1.90 \mathrm{E}-09$ & $1.90 \mathrm{E}-09$ & $1.91 \mathrm{E}-09$ & $1.91 \mathrm{E}-09$ & $\mathrm{Kg}$ \\
\hline nitrous oxide & $3.12 \mathrm{E}-07$ & $1.90 \mathrm{E}-09$ & $1.90 \mathrm{E}-09$ & $1.91 \mathrm{E}-09$ & $1.91 \mathrm{E}-09$ & $\mathrm{Kg}$ \\
\hline nitrous oxide & 0.000491472 & 0.000486289 & 0.000481791 & 0.000535709 & 0.000535008 & $\mathrm{Kg}$ \\
\hline PFC-14 & $3.62 \mathrm{E}-09$ & $3.44 \mathrm{E}-09$ & $3.27 \mathrm{E}-09$ & $4.20 \mathrm{E}-09$ & $4.15 \mathrm{E}-09$ & $\mathrm{Kg}$ \\
\hline $\begin{array}{c}\text { sulfur } \\
\text { hexafluoride }\end{array}$ & $6.93 \mathrm{E}-12$ & $6.82 \mathrm{E}-12$ & $6.72 \mathrm{E}-12$ & $7.99 \mathrm{E}-12$ & $7.97 \mathrm{E}-12$ & $\mathrm{Kg}$ \\
\hline
\end{tabular}

Green house gas emission is considered as output in this research, this study also consider several resources which will be needed. From this input and output, DEA will assess which scenario is performs better than other scenarios. This study considers water resource that used from each scenario such as freshwater, ground water, and sea water. From DEA, scenario 3, 4, and 5 show the most effective and efficient of input and output. This result strengthens the result from green house gas result. The study pointed out that landfill is no longer appropriate to maintain plastic waste in the future. Recycling and incinerator system will be needed to avoid environmental impact in long terms.

\subsection{Simulation Result}

Simulation from the model which described in Figure 5 conclude that rate of adapting community increasing according to the decreasing cost which will be spent by community. Number and rate of arguing community decreasing following to the increasing number and rate of adapting community. There is changing behaviour from arguing community to adapting community. Number and rate of careless community increasing in first half of simulation which caused by number of arguing community are higher than adapting community.

However, rate of careless community decreasing in second half of simulation which caused by number of adapting community started to be higher than arguing community. This simulation concluded that changing cost is important key factor to maintain an increasing number of communities who will adopt the system which support plastic recycling. The change in cost can be maintained by analyzed the possible cost variables that influence the cost which will be spent by community. One key action that can be taken is government's subsidy in order to decrease the cost. This simulation using agent-based modelling and simulation by using SOARS software. The limitation of this simulation is there are cost variables that have not been added into the changing process of cost in the general term which totally spent by community. 


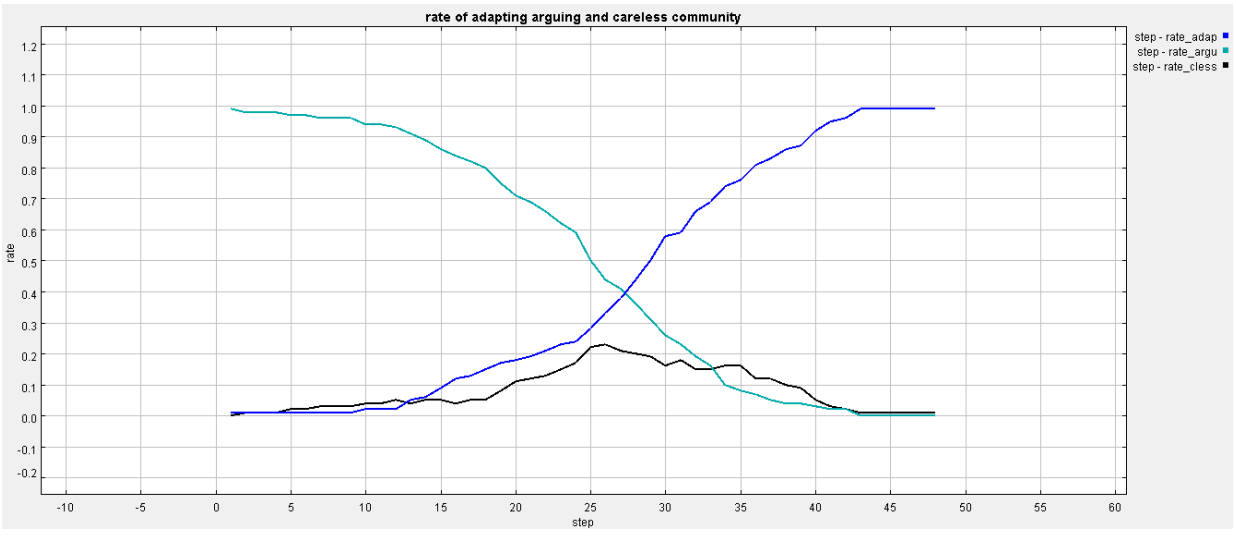

Fig. 5. Rate of Adapting, Arguing, and Adapting Community.

Table 4. Observation findings.

\begin{tabular}{|c|c|c|}
\hline Findings & Observation & Interpretation \\
\hline $\begin{array}{l}\text { Economic class is not directly } \\
\text { affected to } \\
\text { participation in separating their } \\
\text { plastic waste }\end{array}$ & $\begin{array}{l}\text { Several communities who collected } \\
\text { their plastic waste located in area } \\
\text { where only accessible by walking } \\
\text { or motorcycle. } \\
\text { Several communities who collected } \\
\text { their plastic waste working as blue- } \\
\text { collar labour or subcontract worker } \\
\text { or small stall owner. } \\
\text { There is a waste bank's customer } \\
\text { live in a well developed house, } \\
\text { however in her complex' area, she } \\
\text { is the only one customer. }\end{array}$ & $\begin{array}{l}\text { The area of household, type of } \\
\text { community's occupancies is show } \\
\text { that the community live in a low- } \\
\text { middle economic class. } \\
\text { There are customers live in a } \\
\text { middle economic class but they are } \\
\text { minority. }\end{array}$ \\
\hline $\begin{array}{l}\text { Educational background is not } \\
\text { directly affected to community } \\
\text { participation in separating their } \\
\text { plastic waste. }\end{array}$ & $\begin{array}{l}\text { Several of waste bank } \\
\text { administrators especially in waste } \\
\text { bank collector team and several } \\
\text { waste banks' customer are senior } \\
\text { high school educated. } \\
\text { Community in hospital are } \\
\text { controlled by one administrator } \\
\text { who higher educated. }\end{array}$ & $\begin{array}{l}\text { Lower or higher educational } \\
\text { background can be generalized to } \\
\text { be supporting factor of community } \\
\text { participation in separating their } \\
\text { plastic waste. }\end{array}$ \\
\hline $\begin{array}{l}\text { Knowledge is promising factor of } \\
\text { community participation in } \\
\text { separating their plastic waste. }\end{array}$ & $\begin{array}{l}\text { Administrator in hospital, who } \\
\text { control community there, is higher } \\
\text { educated but also know well about } \\
\text { waste management. }\end{array}$ & 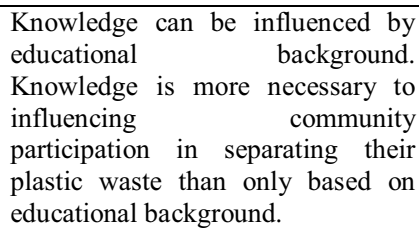 \\
\hline
\end{tabular}

\subsection{Qualitative Data Result}

From observation which gathered in the waste bank, this study pointed out several results. First finding is economic class and educational background is not directly affected to community participation in separating their plastic waste. Other findings is educational background and knowledge in plastic waste management is not directly related, community with better knowledge in waste bank, plastic waste, or recyclable waste is actively participate in separating their plastic waste even their educational background are lower. Thus mean that promotional activities about knowledge in waste bank, plastic waste, or recyclable waste are necessary to be conducted. Several strategies could be conducted 
through social media, local newspaper, or other city information infrastructure. This observation result can be seen in Table 4.

From interview which targeted to several respondents who work as scavengers and cleaning services in local public places, this study pointed out several results and specific needs to be considered in the system. Sustainability and availability of waste separation infrastructure must be maintained in order to support plastic recycling system in community. One respondent pointed out the case of trash basket in Bandung area which are easy to be disappeared or destructed or stolen because built from metal which very valuable for some people (metal's monetary value is high in Bandung or other area in Indonesia). Ease of reassemble or collecting or separating plastic waste also considerable to support a better performance in plastic recycling system. Other respondent claimed that collecting or separating plastic waste from other kind of waste in Bandung is still difficult and take a long time. Cleaner and drier condition of waste storage also will support the quality of plastic waste which ready to be recycled. Respondent who work as cleaning service noted that because of plastic waste still mixed with other kind of waste, they often find that plastic waste is already contaminated by water or any liquid from other waste.

\section{Conclusion}

Plastic waste management in Bandung recently maintained through landfill. This study actually showed that landfill strategy is no longer appropriate to maintain plastic waste. Recycling and incinerator is preferable than landfill strategy. Recycling strategy with landfill as their production waste strategy is considerable than only rely on landfill. From LCA, ABM, and qualitative data collection there are several policies should be necessary to be taken by government. First, plastic recycling and incinerator policy should be considered as main strategy for plastic waste management. Second, subsidy to reduce cost in collecting plastic waste in community should be implemented by maintain sustainable and ease to use infrastructure from household level, waste transportation, and waste storage system. Third, promotional activities in waste bank and plastic recycling system are necessary to be conducted by using social media, local newspaper, and/or other information infrastructure in Bandung area. Plastic waste still increasing and it is promising to reduce waste which will be sent to landfill in order to life cycle of landfill infrastructure. Further study can talk in investment environment to support plastic recycling and incinerator in Indonesia or other city in Indonesia.

\section{References}

1. Hendri, Resyia, Harapan Tua, Jurnal Online Mahasiswa Bidang Ilmu Sosial dan Ilmu Politik, (2012)

2. S. Manfredi, T. H. Christensen, Waste Manag., 29(1), 32 (2009)

3. A.S.E. Yay, J. Clean. Prod., 94, 284 (2015)

4. E. Fikri, P. Purwanto, H. R. Sunoko, Procedia Environ. Sci., 23, 123 (2015)

5. U. Arena, M.L. Mastellone, F. Perugini, Int. J. Life Cycle Assess, 8(2), 92 (2003)

6. F. Perugini, M.L. Mastellone, U. Arena, Environ. Prog. Sustain. Energy, 24(2), 137 (2005)

7. T. Matsuda, J. Yano, Y. Hirai, S.I.Sakai, Int. J. Life Cycle Assess., 17(6), 743 (2012)

8. L.M. Scortar, S. Lazar, L.E. Suciu, Managerial Challenges of the Contemporary Society. Proceedings, 249 (2009)

9. X. Shi, A.E. Thanos, N. Celik, Resources, Conservation and Recycling, 92, 190 (2014) 
10. G. Sauvageau, J.M. Frayret, Eur. J. Oper. Res. 242(3), 987(2015)

11. Y. Liu, H. Ye, J. Clean. Prod., 37, 278 (2012)

12. N.P. Thanh, Y. Matsui, T. Fujiwara, Environ. Monit. Assess., 175(1-4), 23 (2011)

13. H. Bartelings, T. Sterner, Environ. Resour. Econ., 13(4), 473 (1999)

14. F.L. Sahwan, Penelitian Komposisi Sampah (Jurnal Teknologi Lingkungan, Jakarta, 1989)

15. F.L. Sahwan, Penelusuran Pola Sistem Pengolahan Plastik Bekas di Jakarta dan Surabaya (Jurnal Teknologi Lingkungan, Jakarta, 1989)

16. D.R. Wijayanti, S. Suryani, Procedia Soc. Behav. Sci., 184, 171 (2015) 